


\section{الإشادة بالنصر عند الفراعنة}

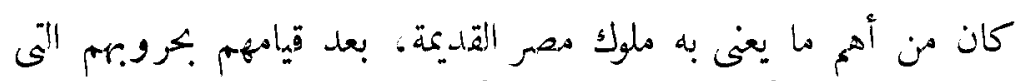

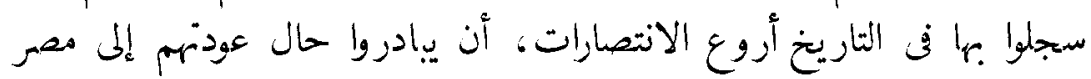

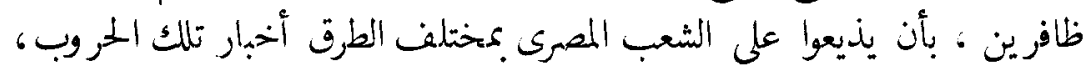

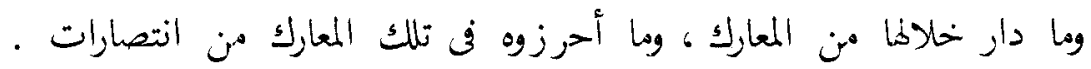

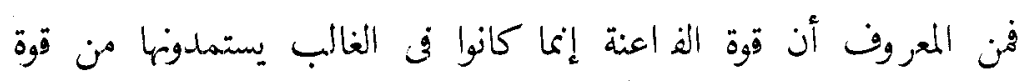

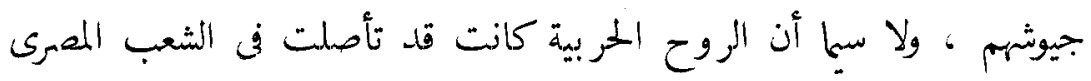

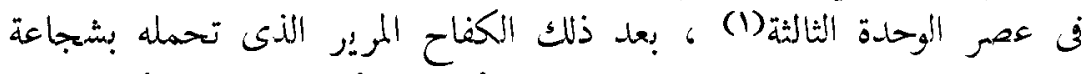

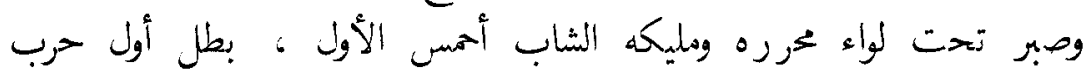

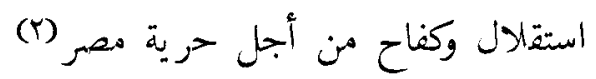

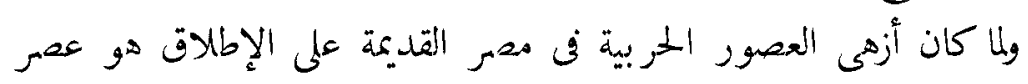

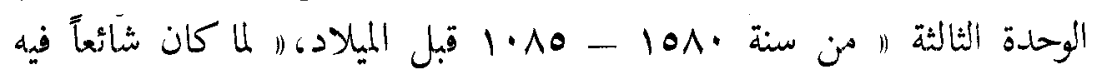

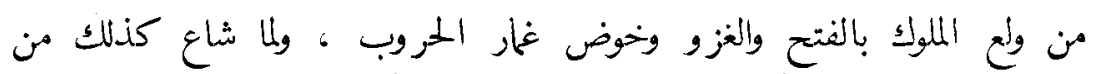

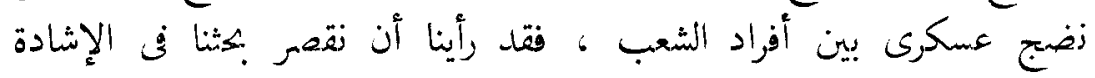

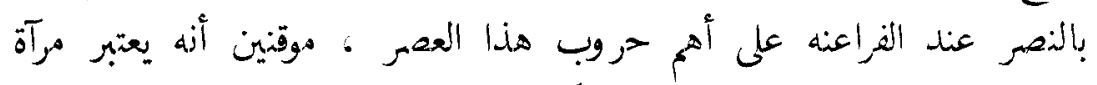

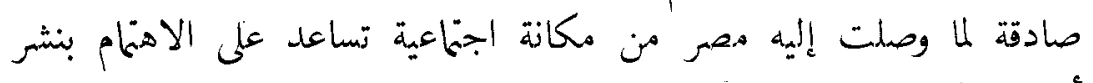

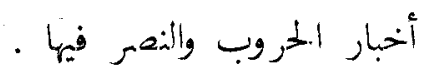

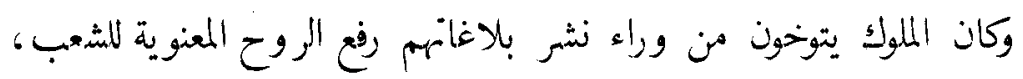

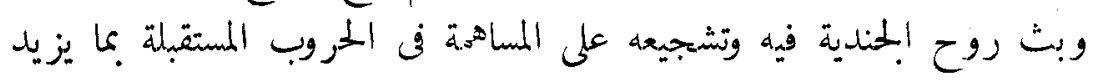

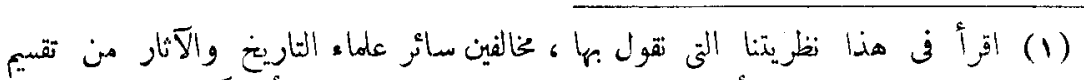

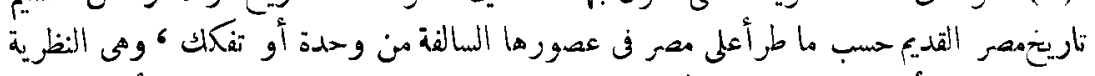

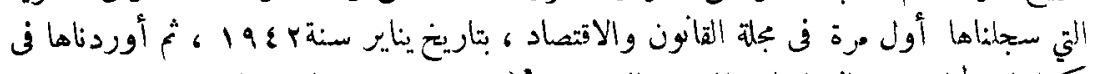

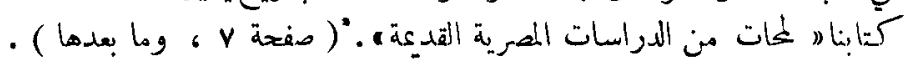
Pahor Labib.Die Herrschaft der Hyksos in Aegypten and ihr Starz, S: 35 ff. 


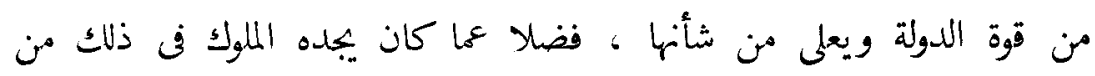

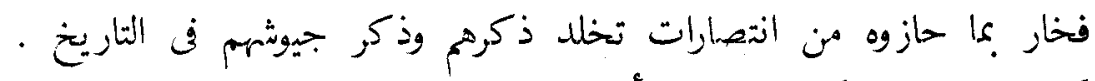

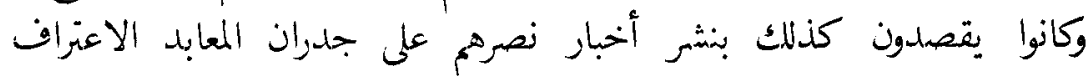

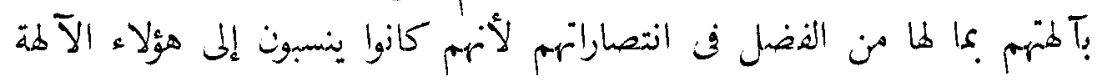

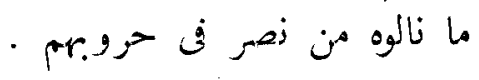

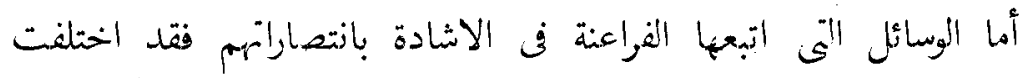

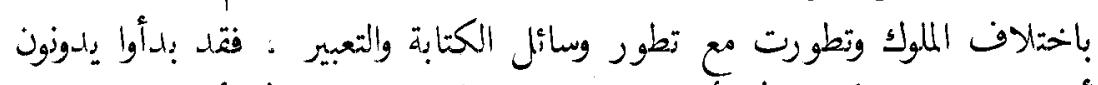

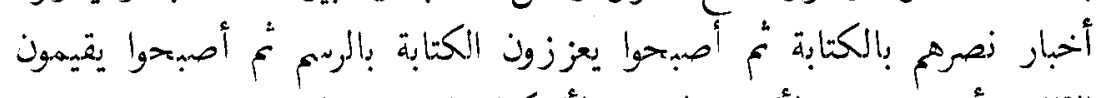

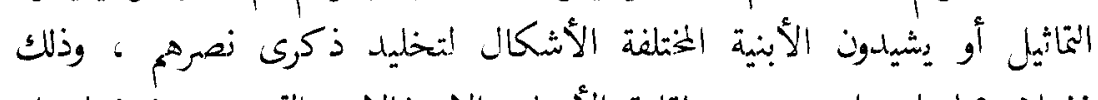

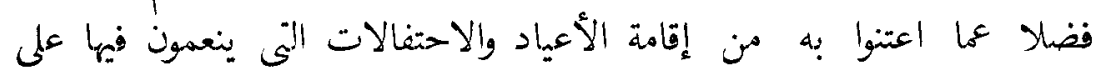

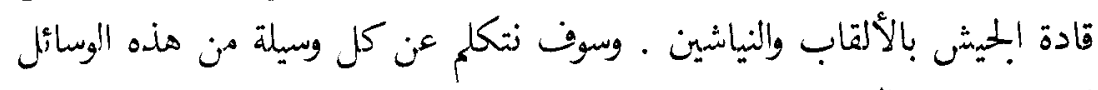

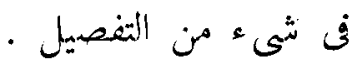

$$
\text { أولا - الكتابة }
$$

فقد بدأ الفراعنة يدونون أخبار زعرهي بالكتابة بأساليب متنوعة وبوسائل

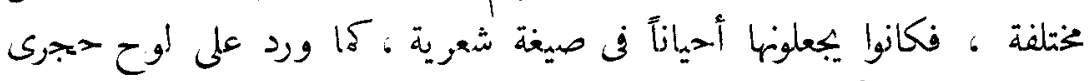

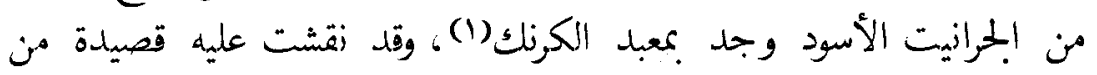

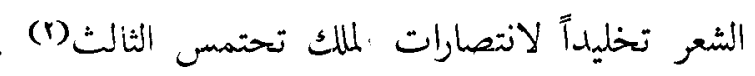

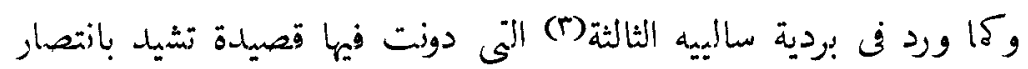

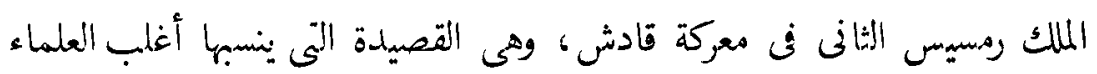

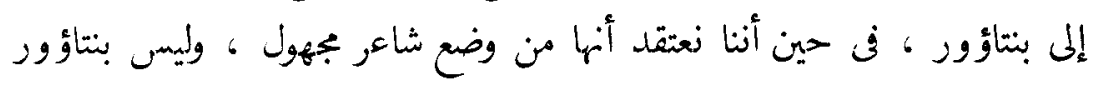

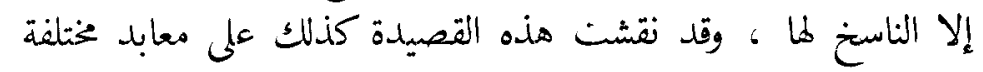
وكانوا يجعلون أخبار نصرهم أحياناً أخرى بصيغة نترية توخوا في مبدأ

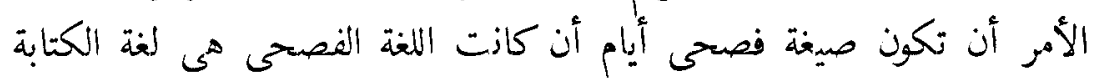

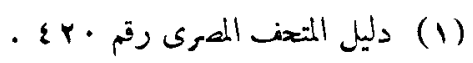

P. Lacau: Stèles du Nouvel Empire.

S. Hassan: Le Poème dit de Pentaour. 


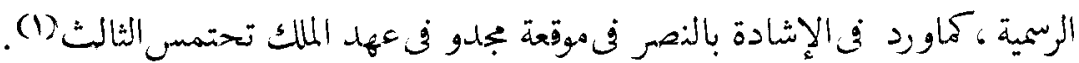

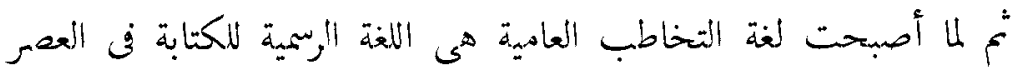

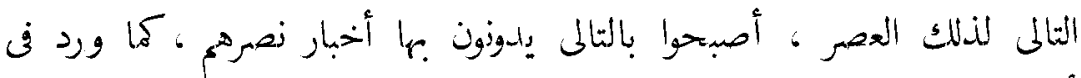

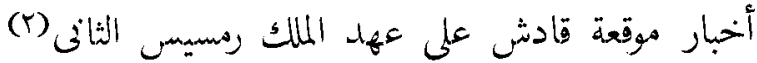

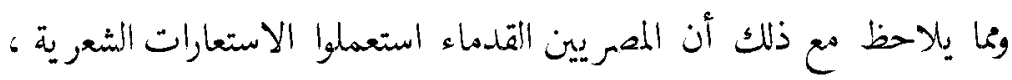

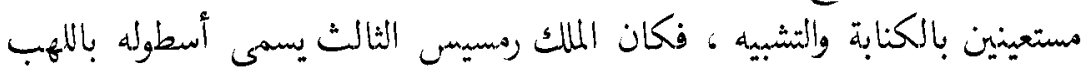

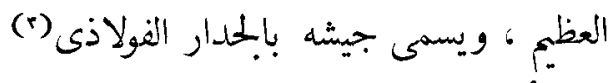

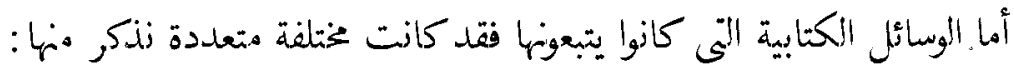

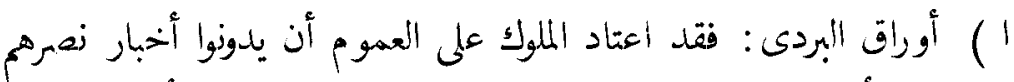

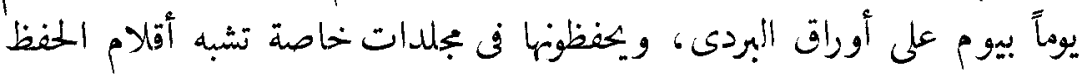

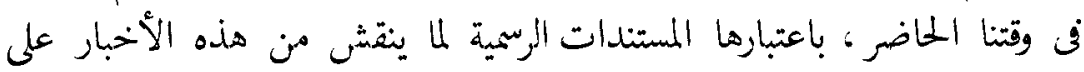

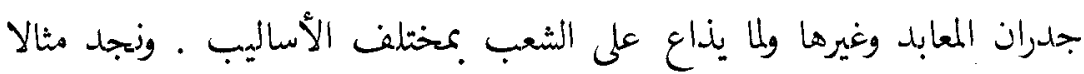

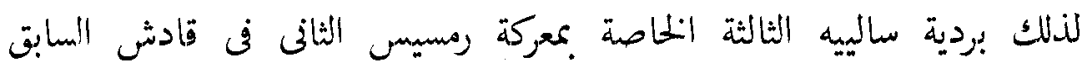

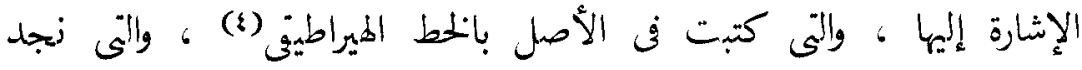

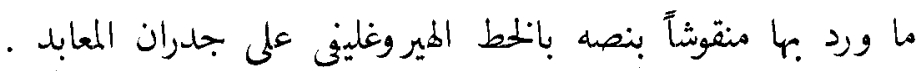

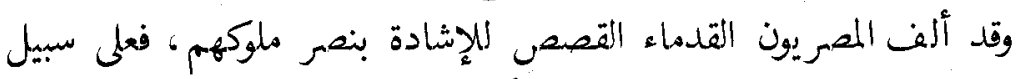

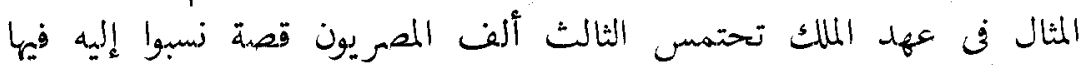

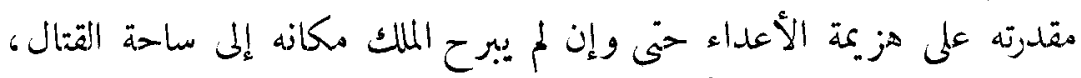

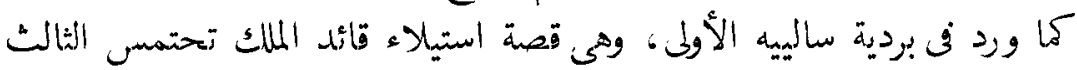

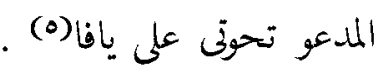

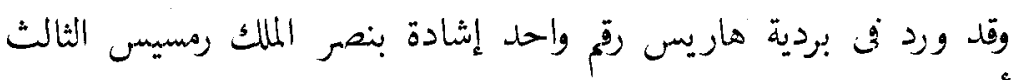

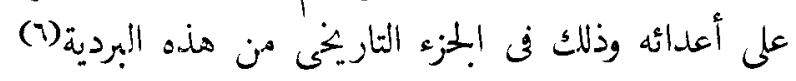

K. Sethe: Urkandan der I8. Dynastie, IV, 625-778.

Ch. Kuentz: La Bataille de Qadech.

H. Grapow: Die Bildlichen Ausdruecke des Aegyptischen, S. I64.

G. Moeller: Hieratische Lesestuecke, zweites Heft.

Pap. Sallier I-3, in the British Museum.

W. Erichsen: Papyrus Harris I, Tafel 76-77. 
ب) جدران المعابد : وقد درج الملوك على الاهنمام بنقش أخبار

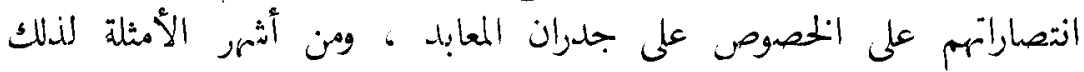

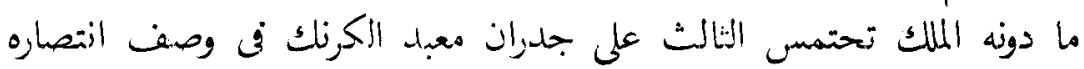

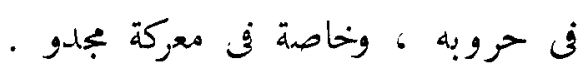

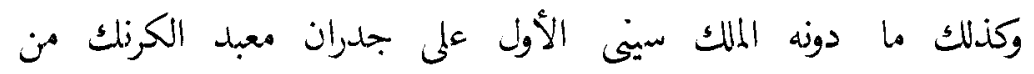

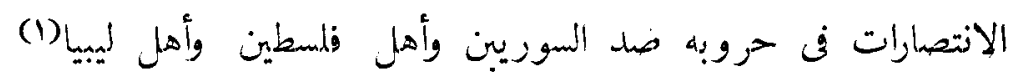

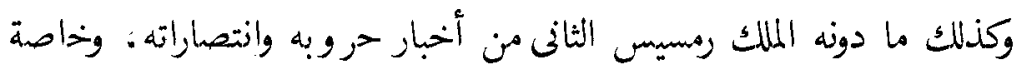

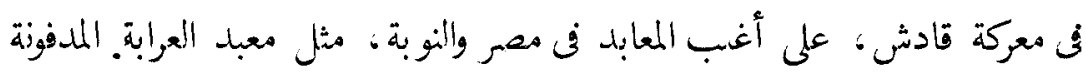

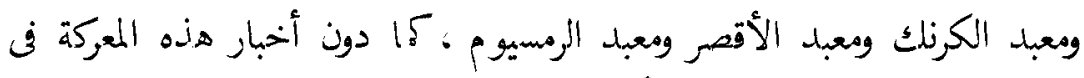

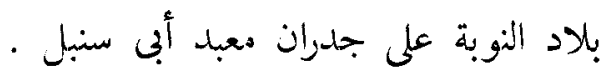

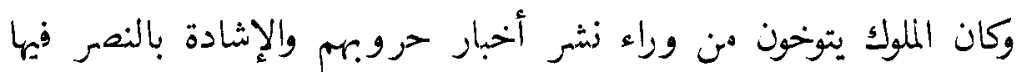

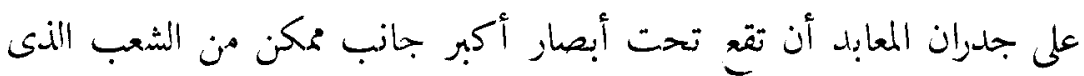

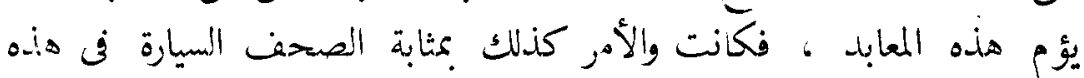
الأيام .

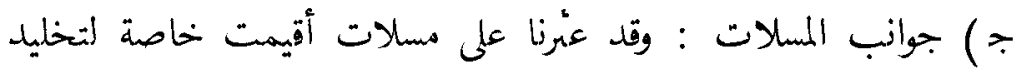

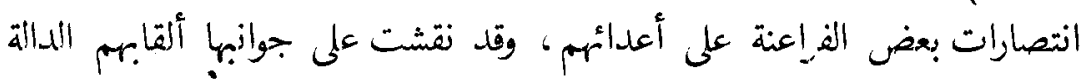

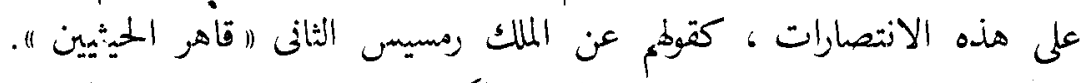

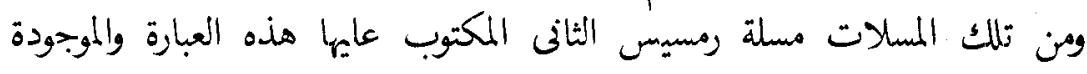
في معبد الكرنك . من الملات مسات

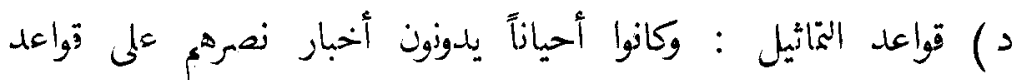

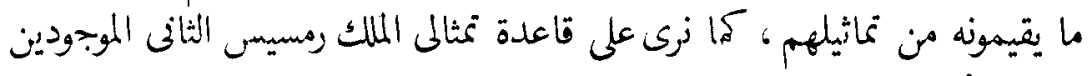

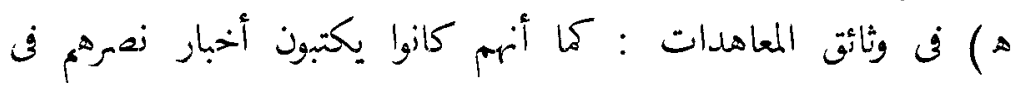

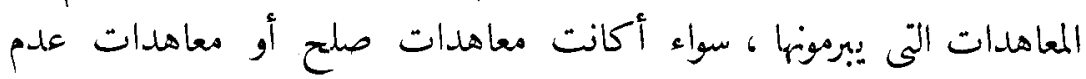

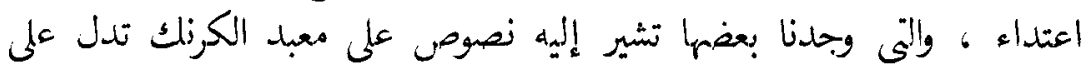

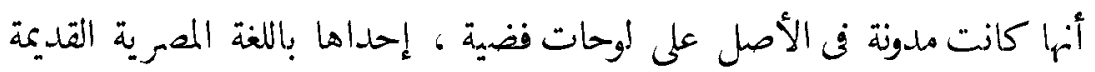




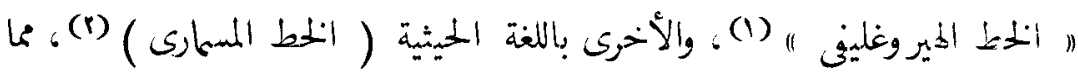

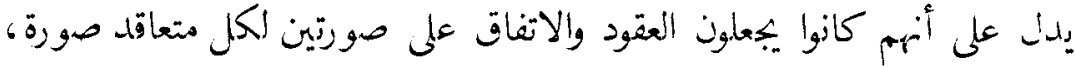

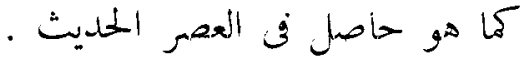

$$
\text { ثازياً - مالريم }
$$

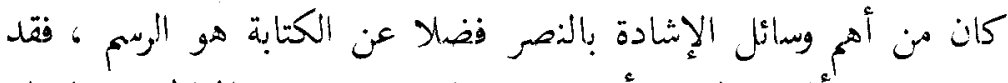

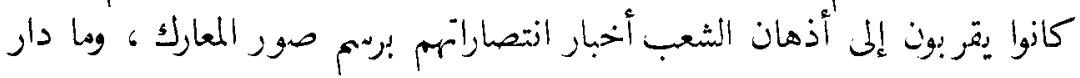

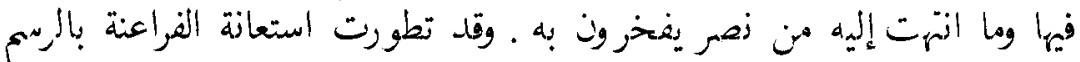

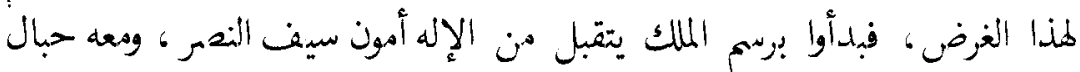

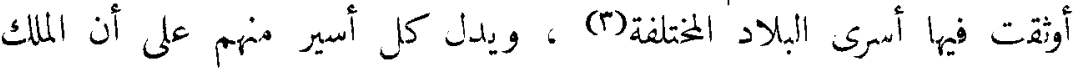

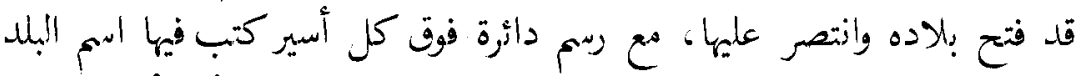

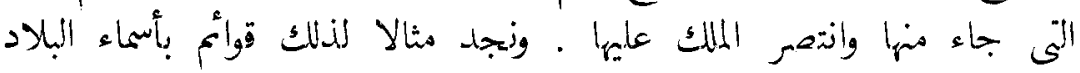

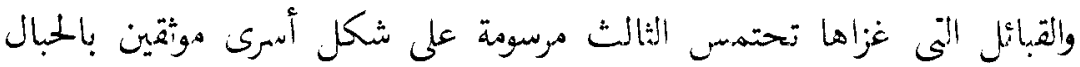

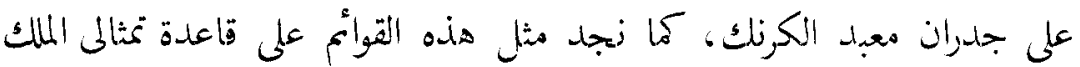
رمسيس الثانى .كمبد الأقصر

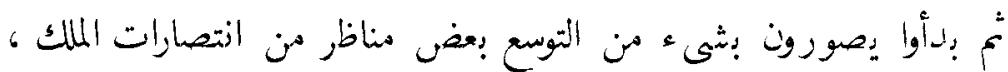

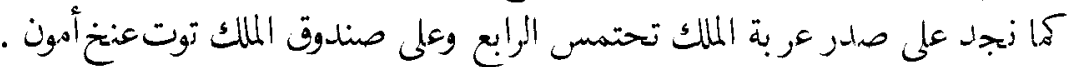

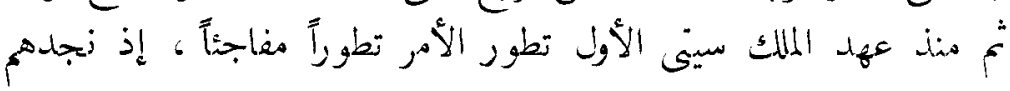

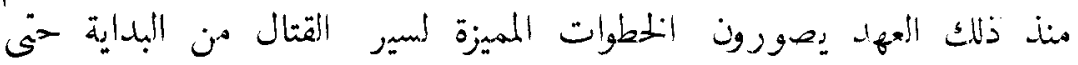

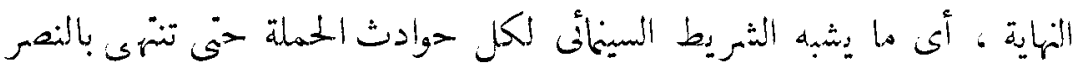

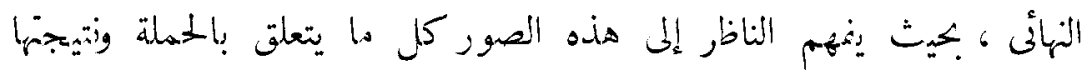

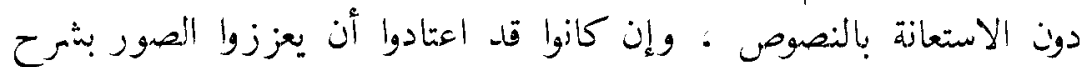

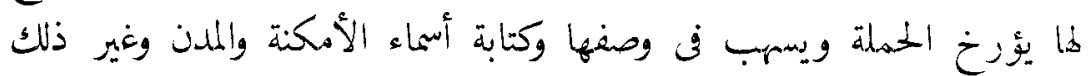

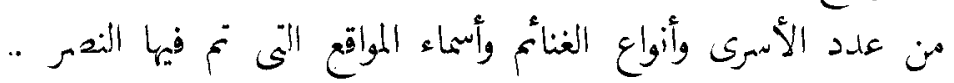

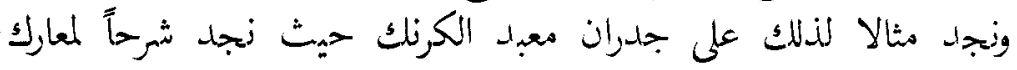

K. Sethe: Nene Forschungen zu den Beziehungen ewischen Aegypten und dem Chattireiche.

S. Langdon and Gardiner, in J. Eg. Arch. VI, 1926.

Lepsius: Denkmawler Abt. III Bl. I79. 


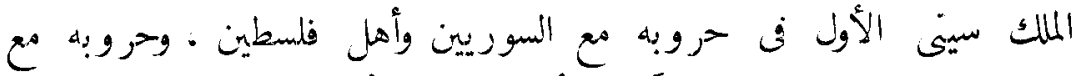

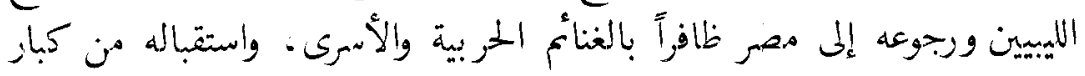

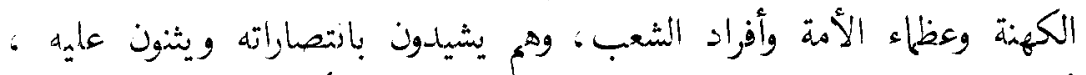

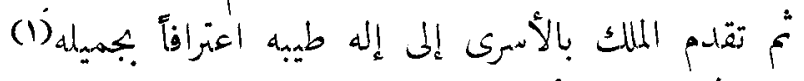

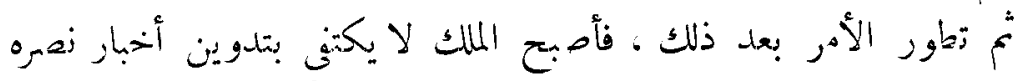

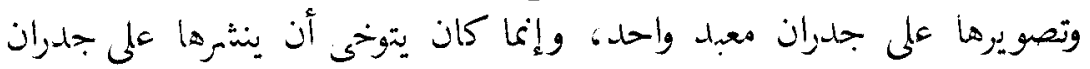

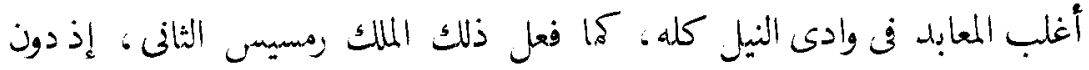

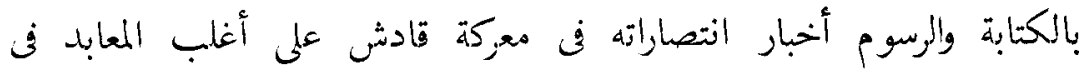

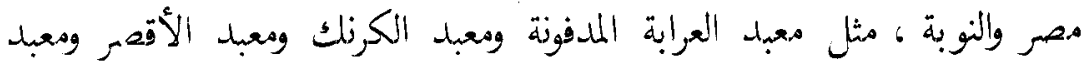

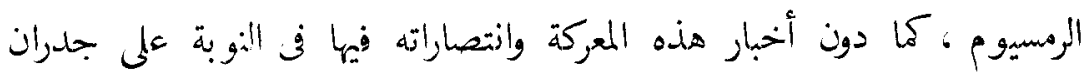
معبد أبى سنبل . ثالثاً - إقامة المّاثيل

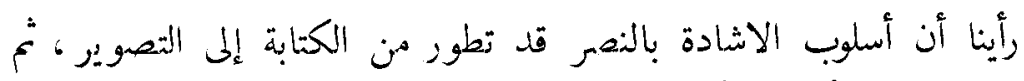

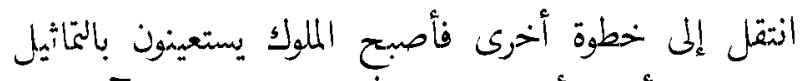

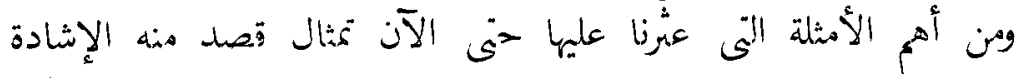

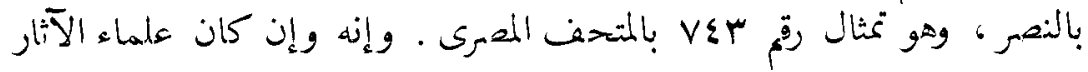

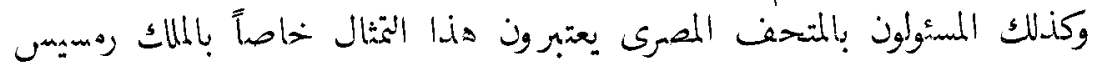

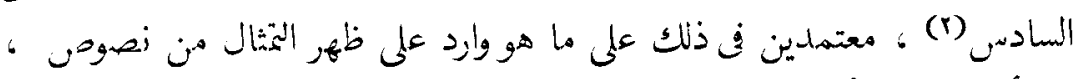

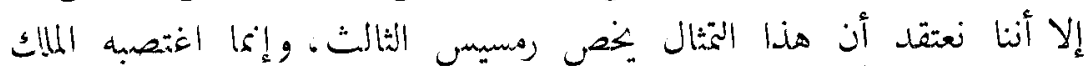

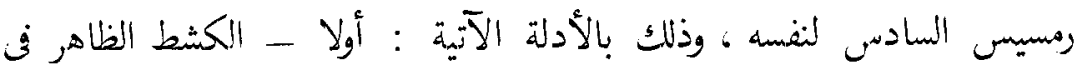

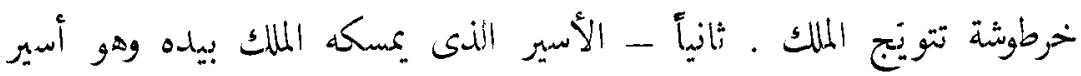

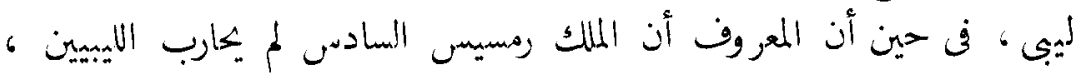
Lepsius, Denkmaeler Abt III Bl. $127 \mathrm{ff}$.

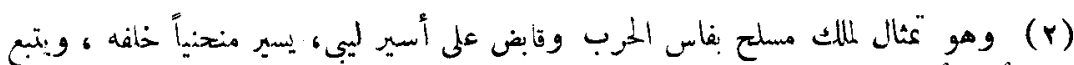

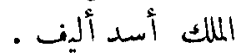

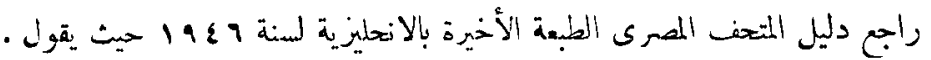
"Curious Statue of King Ramses VI, armed with battle axe and dragging by the hair a Libyan, who walks bent beside him. A tame lion accowpanies the King." 


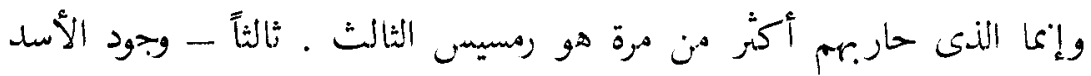

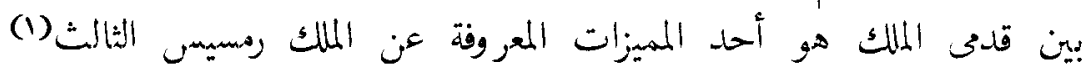

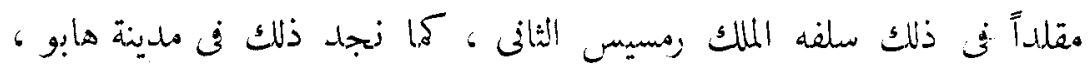

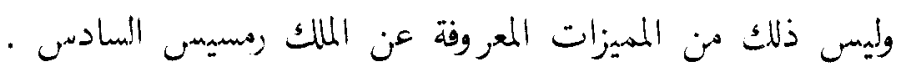

$$
\text { رابعأ - إقامة المبانى }
$$

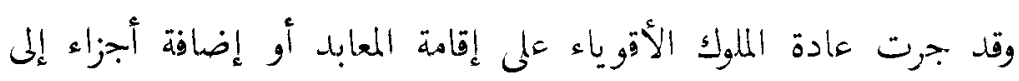

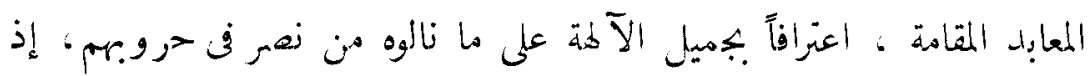

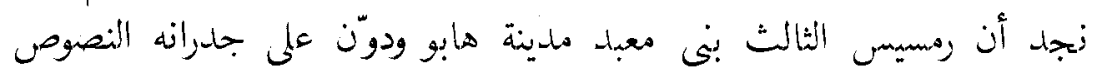

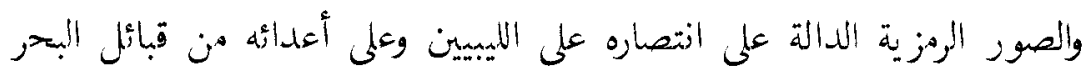

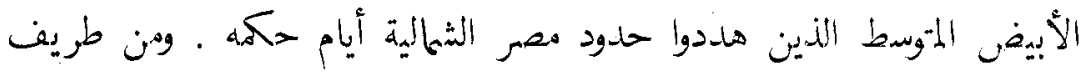

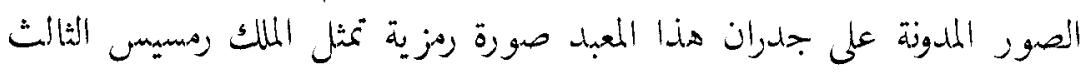

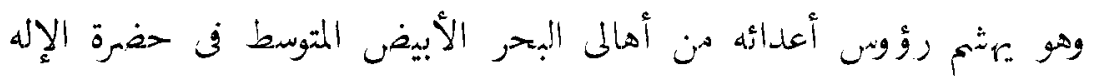

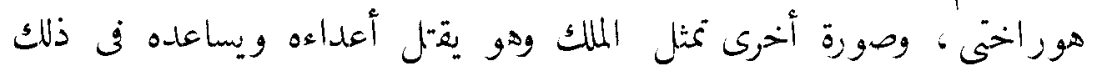

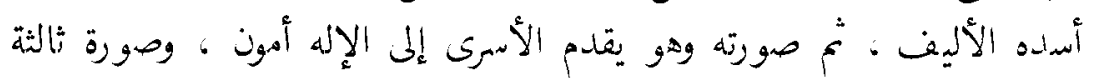

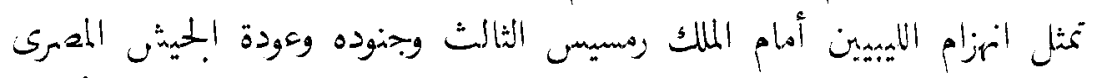

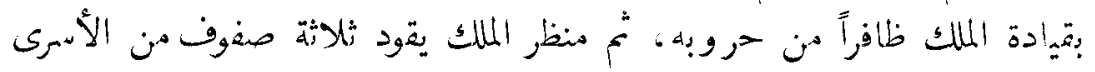

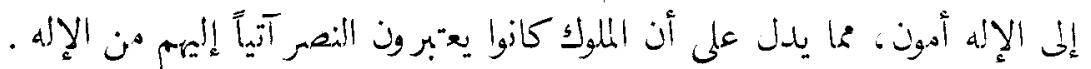

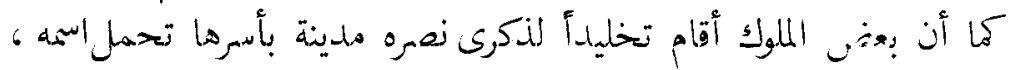

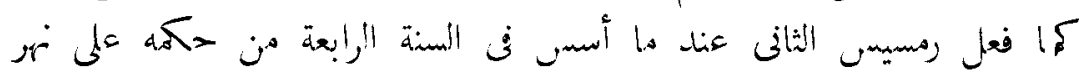

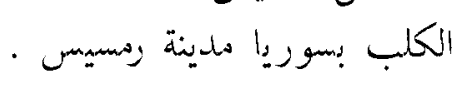

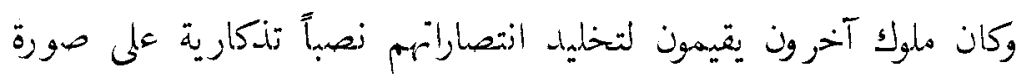

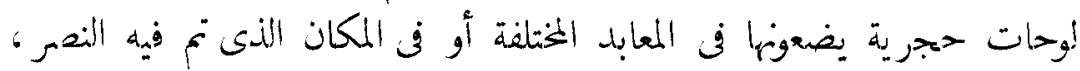

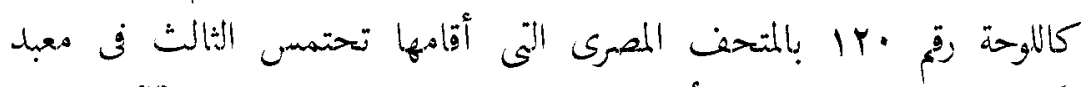

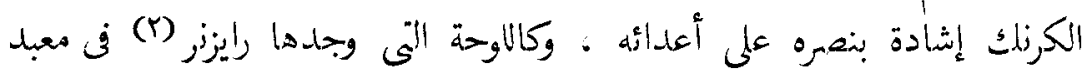

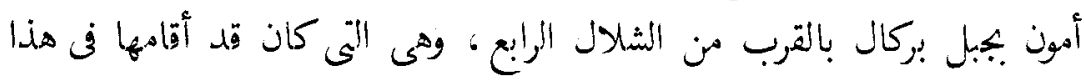

Lepsins: Denkmaeler, Abt. III Bl. 179.

Reisner: A.Z.; 69, S. 24, 1933 . 
المكان تحتمس الثالث إنادة بانتصاره وذاكراً فهيا طرفاً آخر من انتصاراته

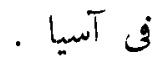

$$
\text { خامساً - حفلات النصر والأعياد }
$$

وكان من أول ما يهم به الملوك بعد عودنهم من حروبهم وانتصازهم فيها

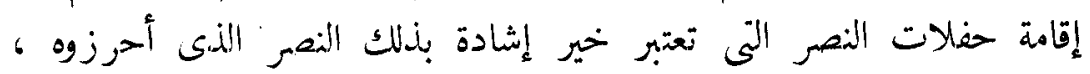

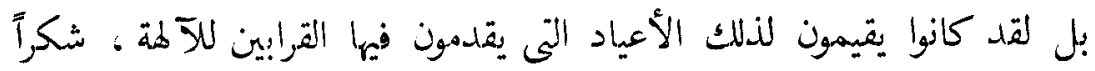

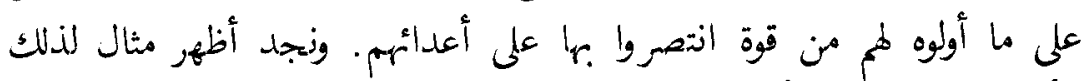

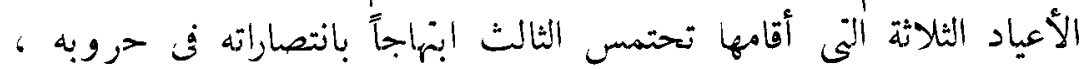

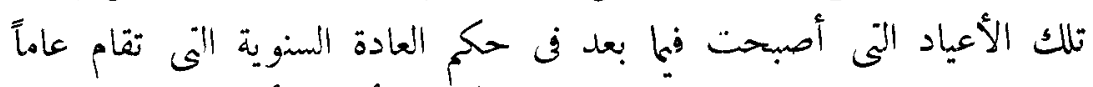

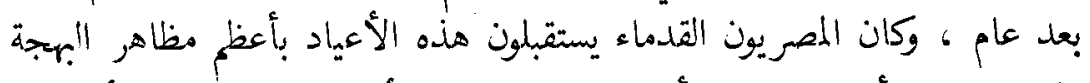

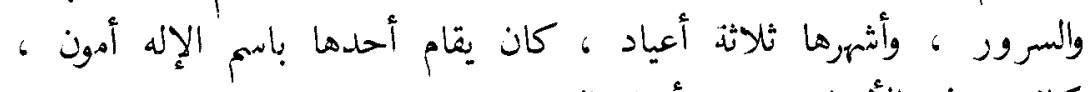

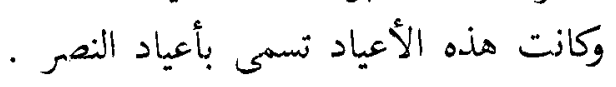

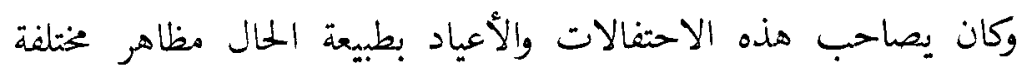

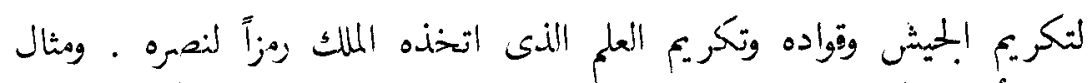

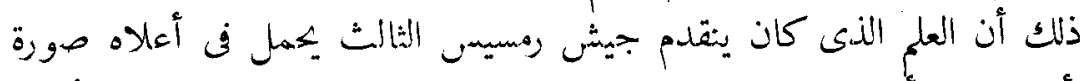

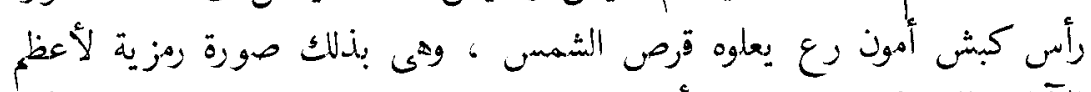

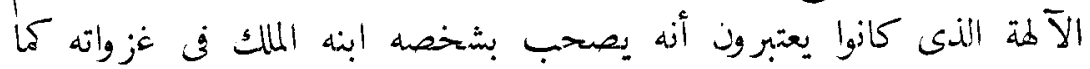

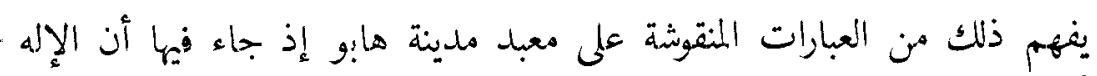

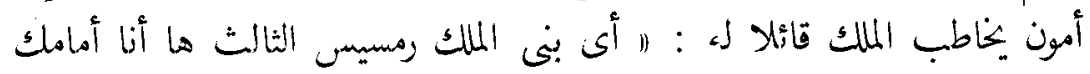

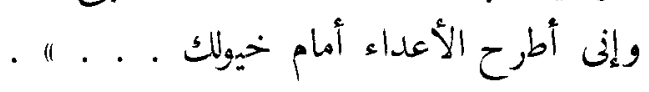
سادسأ _ الأنعام على القادة بالرتب والنياثين وكان من مظاهر الإثادة بالنصر كذلك إنعام الملك على قواده النين

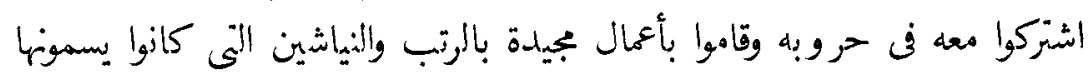

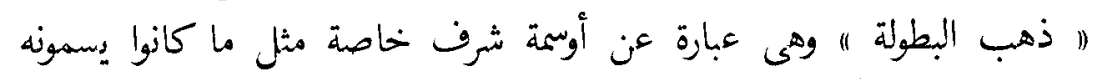

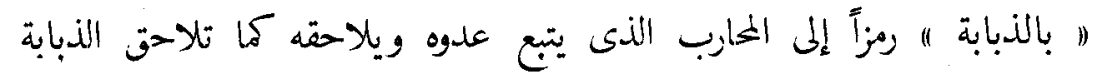


فريسها (1) ، وهى ما يسمونه اليوم اسماً قريباً من هذا الاسم وهو (" الدبورة " .

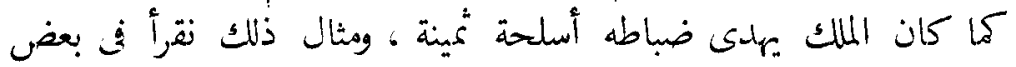

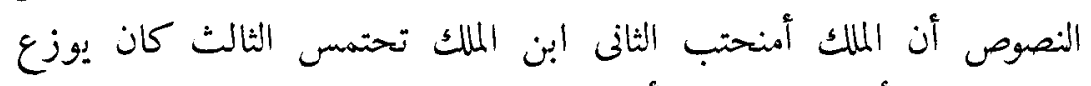

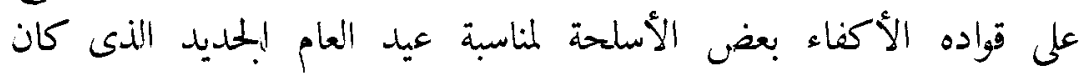

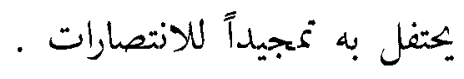

\section{سابعاً - استحضار أهراء البلاد المهزومة}

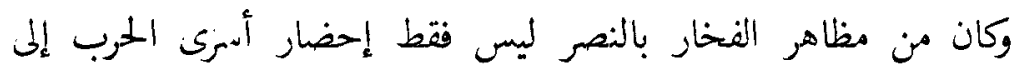

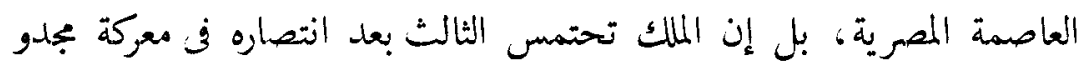

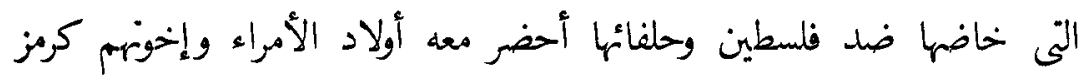

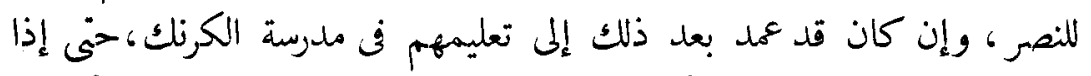

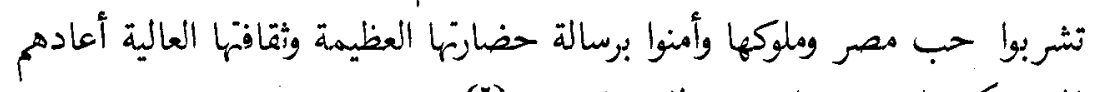

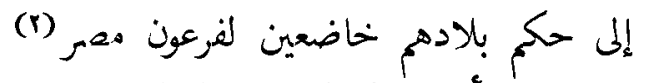

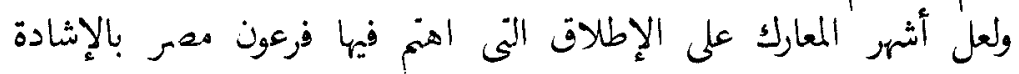

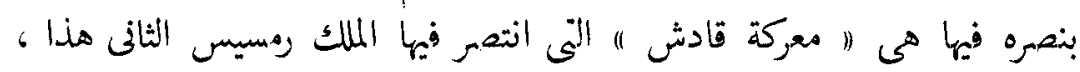

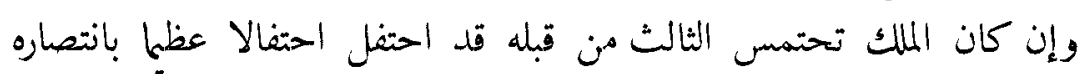

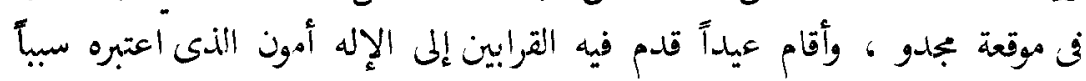

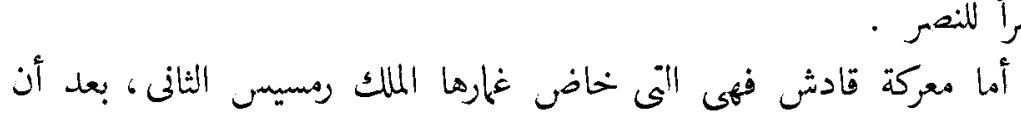

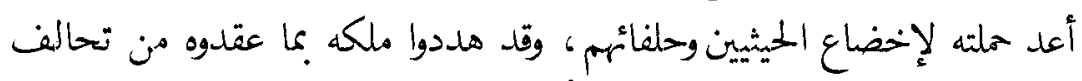

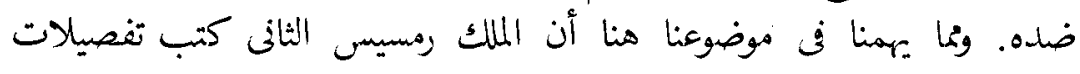

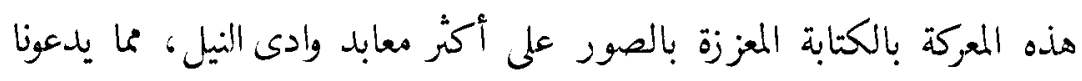

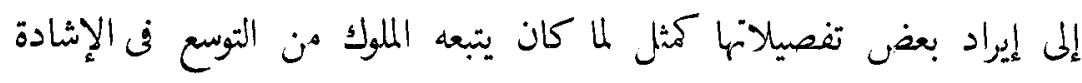

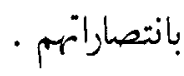

Erman-Ranke: Aegypten S. 63 I

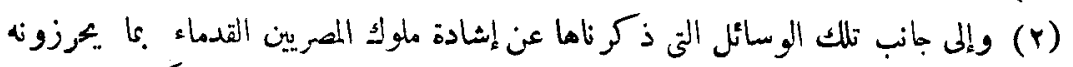

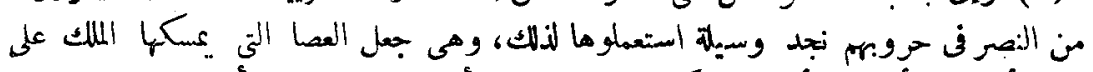

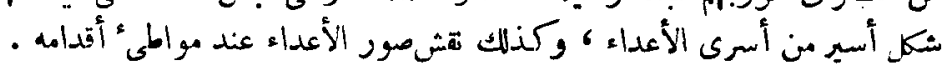




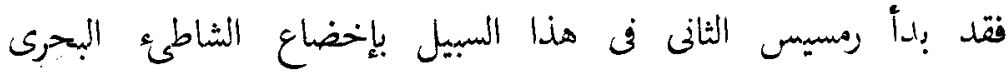

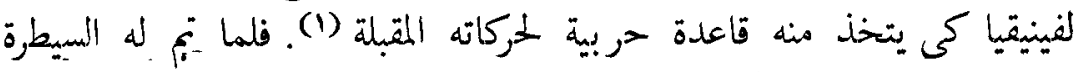

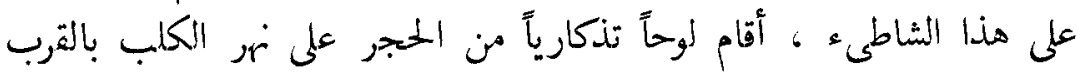

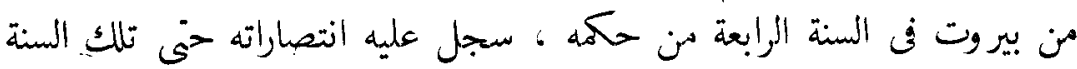

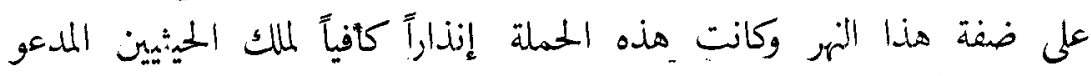

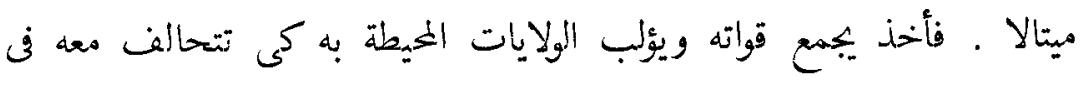

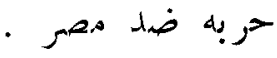

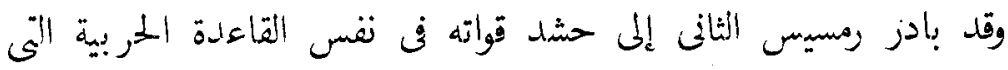

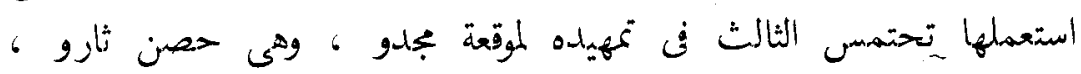

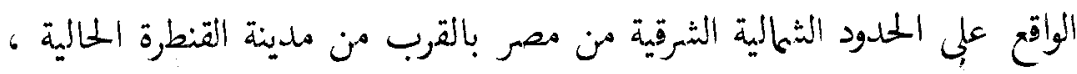

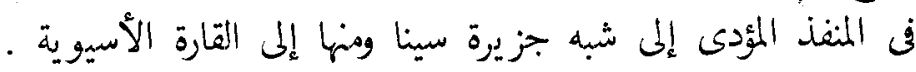

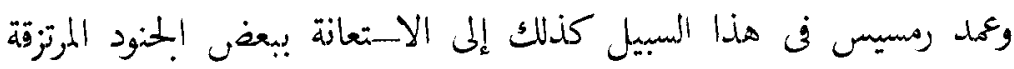

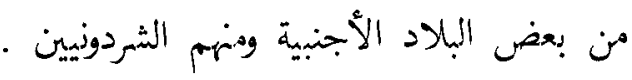

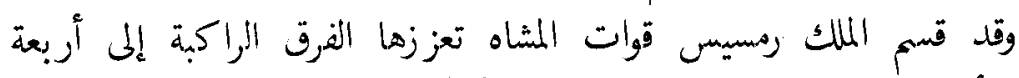

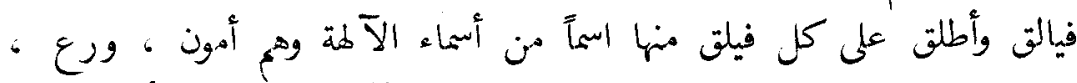

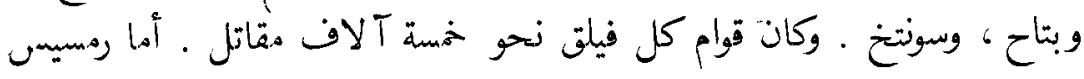

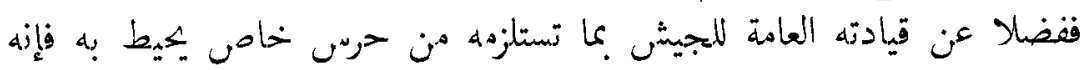
تولى قيادة فيلق المقدمة وهو المسمى بفيلق آهون

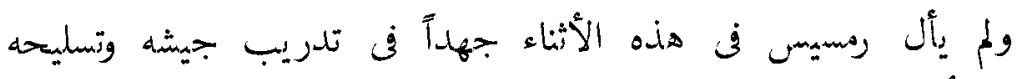

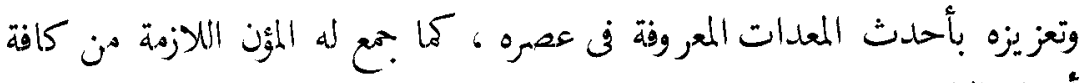

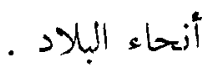

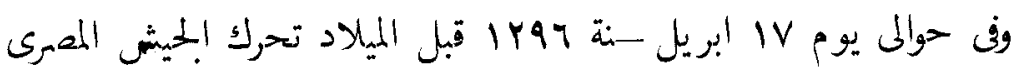

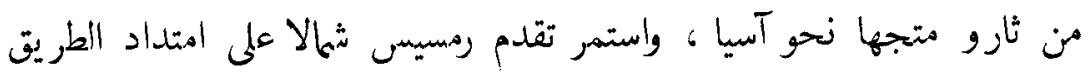

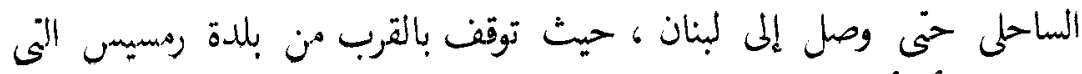

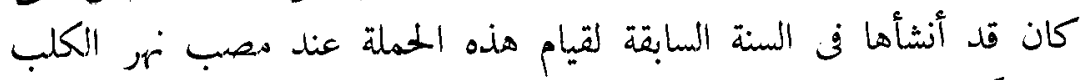

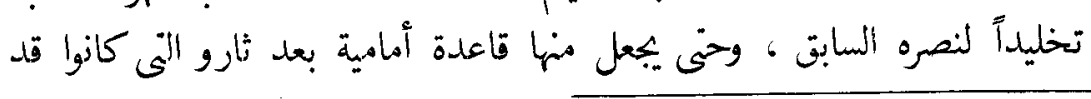

Ed. Meyer: Geschichte II, I.

Ch. Kuentz: La Bataille de Qadech. 
ابتعلدوا عها كثيراً في حين توخى الملك ألا يطيلوا خطوط مواصلاته .

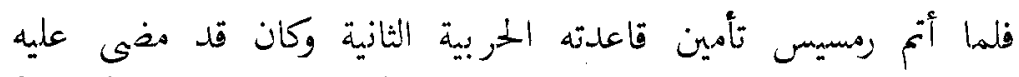

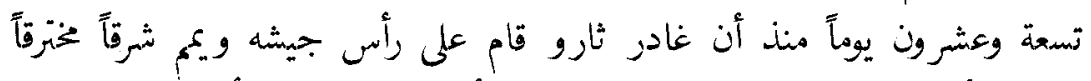

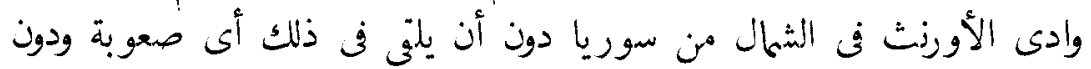

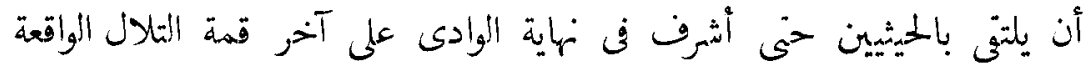

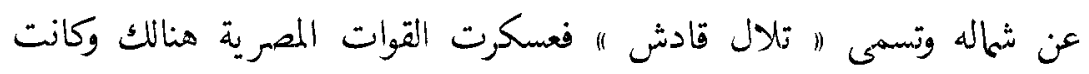

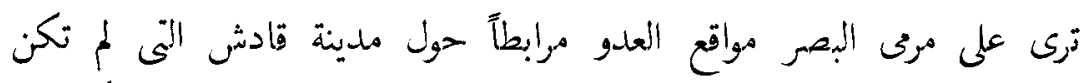

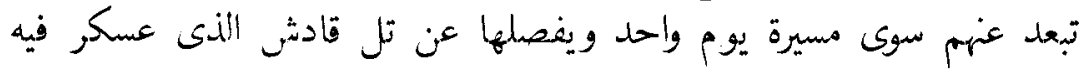

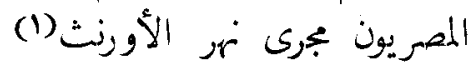

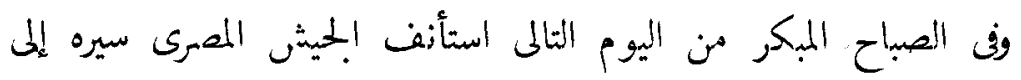

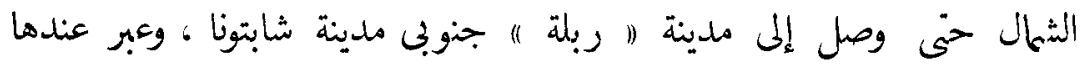

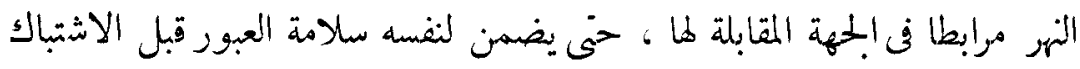

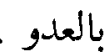

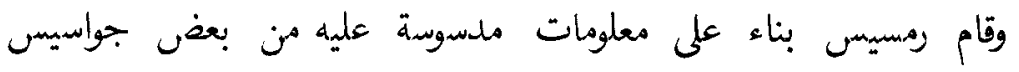

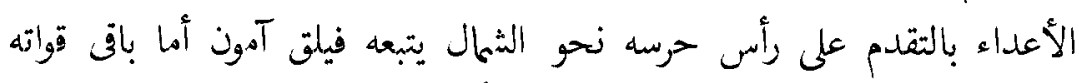

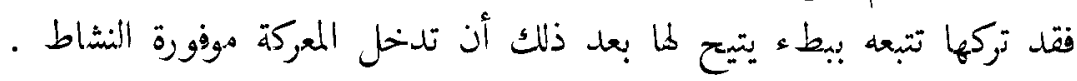

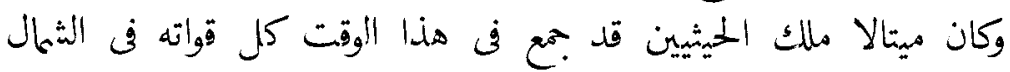

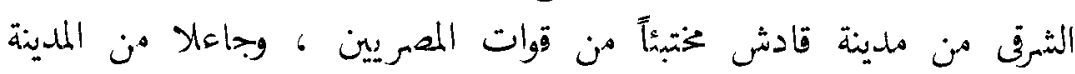

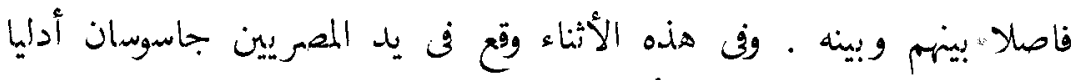

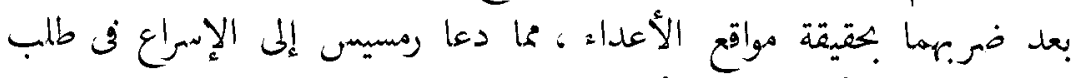

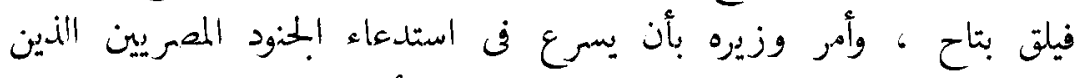

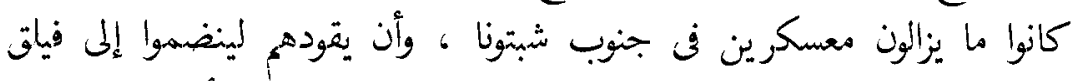

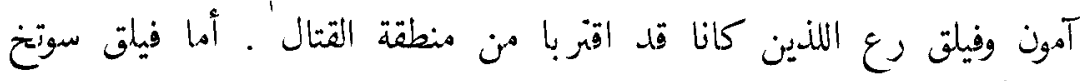

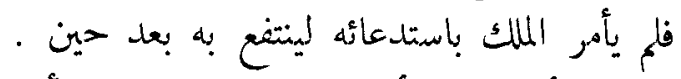

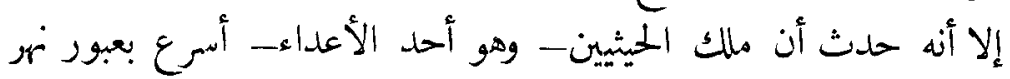

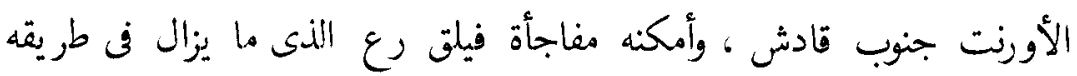




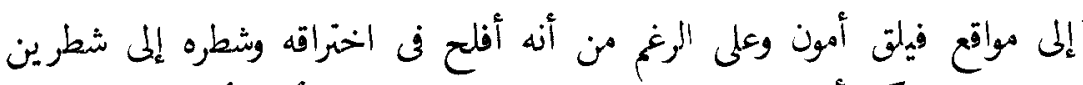

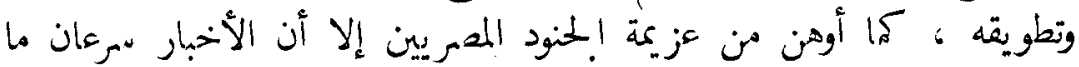

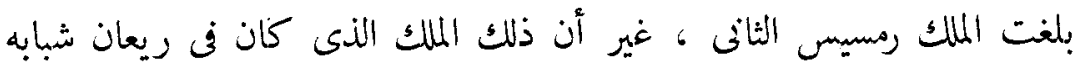

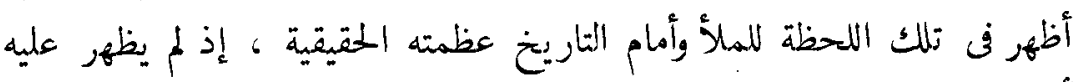

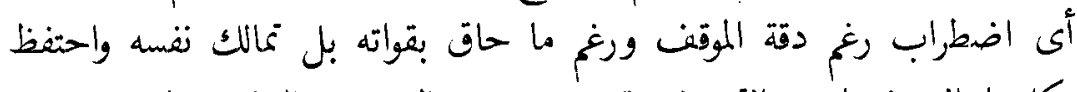

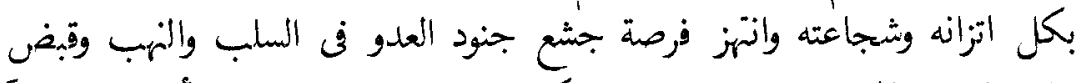

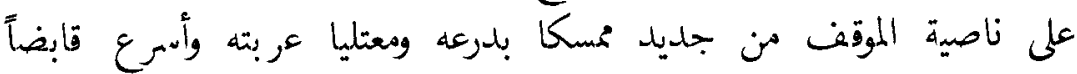

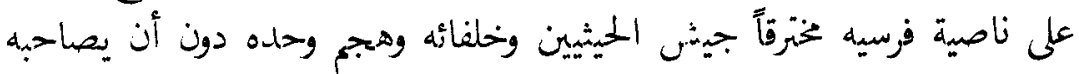

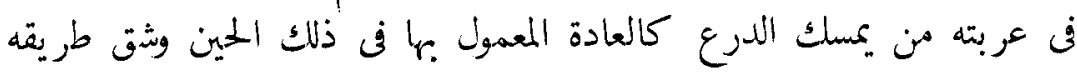

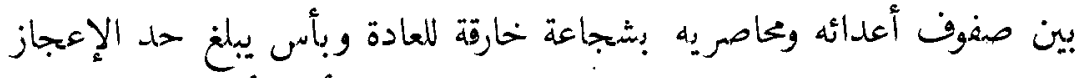

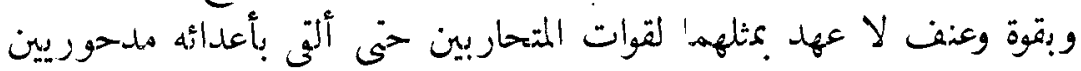

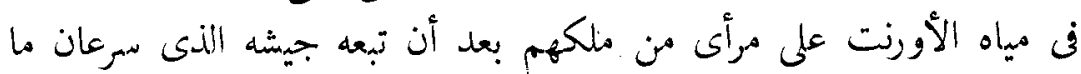

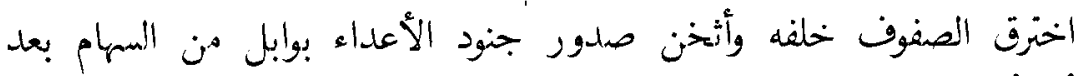

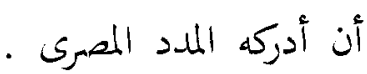

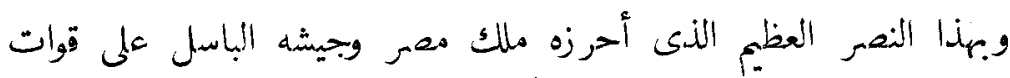

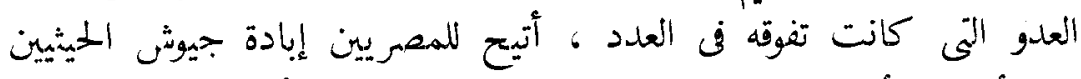

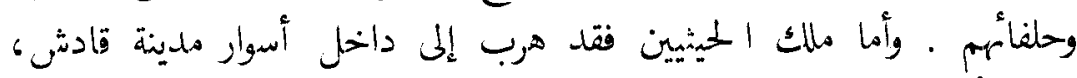

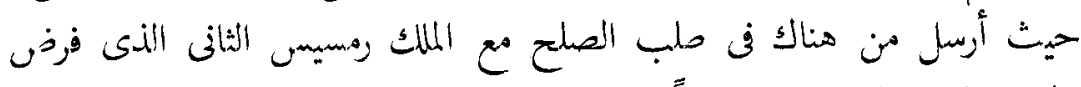

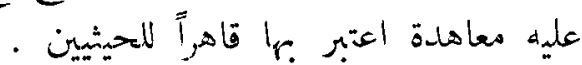

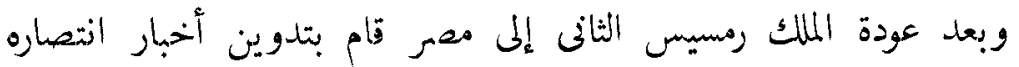

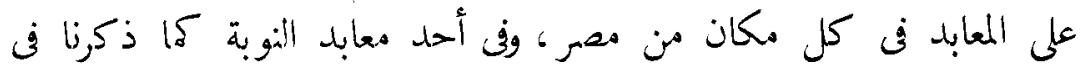

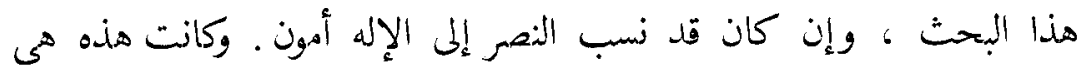

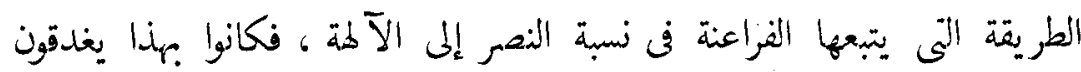

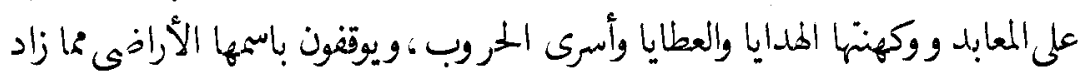

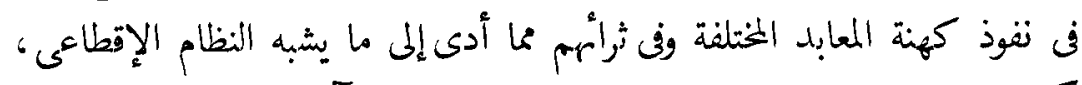

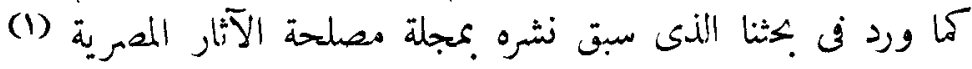

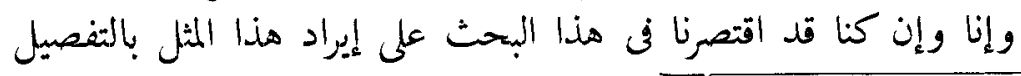

Pahor Labib : Feudalismus. 


\section{9}

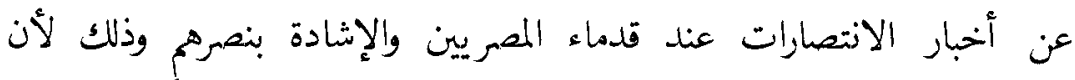

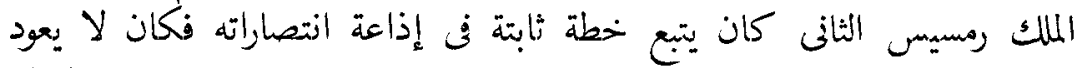

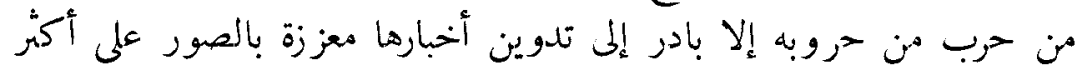

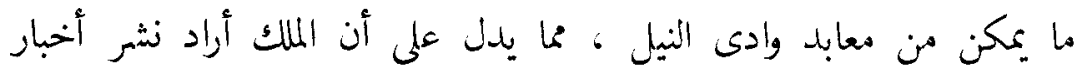

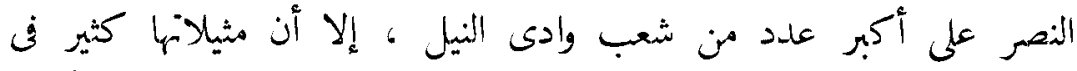

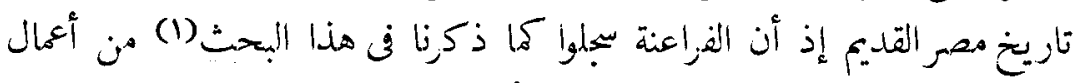

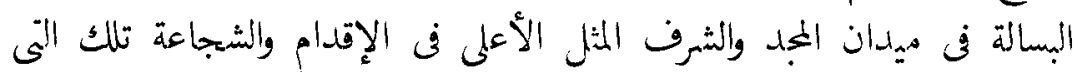

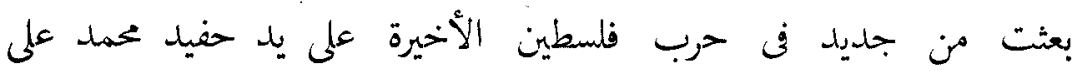

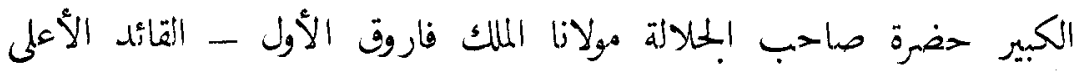

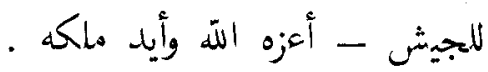

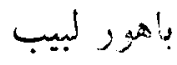

(1) أوردنا بضها بالتفصيل في كتابنا ه الملك رأس السلطات " ، صفحة . A وما بعدما . 